\title{
СИНТАКСА ЗАВИСНИХ РЕЧЕНИЦА У САВРЕМЕНИМ ГРАМАТИКАМА ИТАЛИЈАНСКОГ ЈЕЗИКА
}

У овом раду приказали смо начин проучавања зависних реченица (терминологија, калсификације, теоријски модели) у савременим граматикама италијанског језика узевши у обзир најрелевантније граматичке приручнике објављене у првим деценијама 21. века. Анализа показује да у савременој синтакси зависносложене реченице не постоји хомогени теоријски модел већ је реч о комбинацији традиционалне, генеративне и депенденцијалне граматике. Проучавање зависних реченица темељи се на разлици, уведеној новим лингвистичким теоријама, између обавезних реченица које су део нуклеуса и представљају допуну предиката управне реченице (допунске / тематске / нуклеарне) и необавезних које су ван граница нуклеуса и припадају такозваним реченичним експанзијама (прилошке/ маргиналне / ненуклеарне). Будући да савремени лингвисти заступају овакву двочлану примарну поделу реченица, релативне реченице остају изван ње, те је њихово место прилично недефинисано у класификацијама данашњих граматика. Као највећа класификациона новина показују се тзв. реченице у оквиру синтагме у које се, поред релативних, убрајају и допунске реченице уведене номиналним елементом. Разлике у проучавању зависних реченица своде се данас искључиво на употребу различите терминологије, док по питању класификација постоје два типа граматика: граматике које заступају логичко-семантички критеријум поделе и граматике које заступају како логичко-семантички тако и формални критеријум. Савремена синтакса зависносложене реченице се у односу на традицију највише разликује у погледу примарне поделе реченица која више није трочлана (допунске, придевске, прилошке) већ двочлана (допунске и маргиналне) као и у поједностављивању класификација и изостављању неких „традиционалних“ врста зависних реченица (месне, изјавне).

Кључне речи: зависне реченице, нуклеус, реченичне експанзије, допунске реченице, прилошке реченице

*_marijamitrovic@fil.bg.ac.rs 
Марија Митровић

\section{1. Увод}

Прекретницом богате и плодотворне италијанске граматикографије, чији корени сежу до средине 15. века односно до дела Лоренца Албертија (Lorenzo Alberti) које представља прву граматику италијанског језика али и уопште прву граматику једног народног језика у Европи, сматра се 1988. година у којој је, поред још два врло значајна

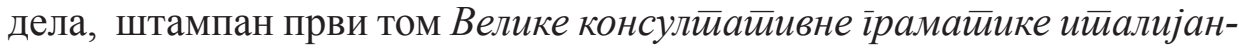
скої језика (Grande grammatica italiana di consultazione), најзначајније и најобимније синтаксе италијанског језика. Иако у деценијама које су претходиле овом моменту италијанска лингвистика није заостајала за светском лингвистиком у погледу прихватања и увођења нових лингвистичких теорија ${ }^{1}$, седамдесетих и осамдесетих година италијански, али и страни лингвисти, и даље указују на проблем непостојања добре и свеобухватне граматике италијанског језика и неопходности што хитнијег састављања једног таквог дела. Управо почетком осме деценије двадесетог века, велики италијански лингвиста Ђулио Лепски (Giulio Lepschy 1972: 3) констатује врло отворено да не постоји италијанска граматика или да барем не постоји онаква какву „бисмо желели“ или какву „би желели неки од нас“ те да су „сви уморни од слушања шта би требало урадити уместо тога шта је урађено или шта се тренутно ради“ истичући притом да је у том тренутку већ општеприхваћено да та граматика мора бити генеративна. Лепски (ibid: 6,7) као да „призива“ управо онакво дело какво ће

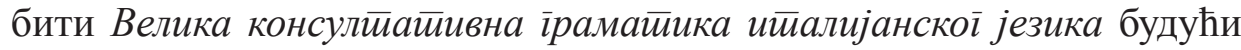
да истиче неопходност стварања референтне граматике намењене пре свега лингвистима, а не широј публици јер управо могућност стварања добрих практичних граматика зависи од могућности позивања на добру референтну граматику. Истиче (ibid: 11) такође да та граматика мора бити дескриптивна, а никако нормативна.

1 Ваља нагласити да је генеративна граматика Ноама Чомског (Noam Chomsky) одмах пронашла своје присталице у италијанској лингвистици тако да су прве генеративне граматике италијанског језика угледале светлост дана већ крајем шездесетих и почетком седамдесетих година (Костабиле (Costabile1969), Салтарели (Saltarelli1970), Гамберини (Gamberini1971), Паризи \& Антинучи (Parisi \& Antinucci1973)). 
Управо овакви и слични повици великих италијанских и светских лингвиста утрли су пут великој промени која се догодила 1988. године која је и остала упамћена као година преокрета (l'anno della svolta) односно као annus mirabilis италијанске граматикографије како је то истакао Бласко Ферер (Blasco Ferrer 1990: 185). Година 1988. дефинише се годином великог преокрета у савременој италијанској граматикографији стога што су у размаку од само неколико месеци светлост дана угледала три ${ }^{2}$, међу собом различита, али подједнако значајна дела након неколико деценија, не толико граматикографске стагнације јер је продукција граматичких приручника била врло жива, колико безуспешних покушаја да се изнедри дело које ће на свеобухватан начин описати савремени италијански језик.

Након овог готово револуционарног обрта продукција граматика постаје све богатија, а аутори се све више, иако не недостају дела окренута традиционалној граматици, окрећу новим лингвистичким теоријама то јест, најчешће, плодовима генеративне граматике и осталих теорија насталих у њеним оквирима. Савремену италијанску граматикографију карактерише обиље граматичких приручника различитих теоријских модела али и степена позивања на традиционалну граматику тако да се може закључити да у данашњој италијанској науци о језику не постоји хомогена лингвистичка теорија, будући да у целини није заступљен ни традиционални али ни генеративни или депенденцијални модел због чега савремене граматике најчешће бивају дефинисане „модерним“ (Ванели (Vanelli 2012)) односно „новим“ (Андреозе (Andreose 2017)) граматикама италијанског језика како би се разликовале од граматика написаних према постулатима традиционалне граматике.

Циљ нашег рада јесте да прикажемо тендеције у проучавању зависноложене реченице управо у тим „модерним“ односно „новим“ граматикама италијанског језика испитујући терминологију, класификације зависних реченица али и теоријске моделе у оквиру којих су ова дела настала. Ограничићемо се на раздобље од 2000. до 2016. године анализирајући седам најзначајнијих граматика објављених током ових шеснаест година: Grammatica italiana di base Пјетра Три-

2 Остала два дела су: Grammatica italiana Луке Серијанија (Luca Serianni) и Grammatik del italianischen Sprache Кристофа Шварцеа (Christoph Schwarze). 
фонеа и Масима Палерма (Pietro Trifone \& Massimo Palermo 2000), La grammatica italiana Чечилије Андорно (Cecilia Andorno 2003), Lingua italiana. Una grammatica ragionevole Марије Грације Ло Дука и Розарије Соларино (Maria Grazia Lo Duca \& Rosaria Solarino 2004), Le regole e le scelte. Introduzione alla grammatica italiana Микелеа Прандија (Michele Prandi 2006) $)^{3}$, Grammatica di riferimento dell'italiano contemporaneo Ђузепеа Патоте (Giuseppe Patota 2006), Sistema e testo. Dalla grammatica valenziale all'espressione dei testi Франческа Сабатинија, Кармеле Камодека и Кристијане Де Сантис (Francesco Sabatini, Carmela Camodeca \& Cristiana De Santis 2011), Grammatica: parole, frasi, testi dell'italiano Анђеле Ферари и Лучана Цампезеа (Angela Ferrari \& Luciano Zampese 2016). Из наше анализе ће бити изостављене граматике које се заснивају искључиво на традиционалном моделу (Ронкорони (Roncoroni 2005), Кастеларо (Castellaro 2006), Панебјанко и др. (Panebianco et al. 2012)) будући да је циљ нашег рада управо указивање на одступање од традиције то јест на постојеће новине у синтакси зависносложене реченице. Такође, из наше анализе ће бити изузета граматика Салви \& Ванели (Salvi \& Vanelli 2004), али не из истог разлога као претходне већ због тога што се ово дело у потпуности, барем што се тиче анализе зависносложене реченице, ослања

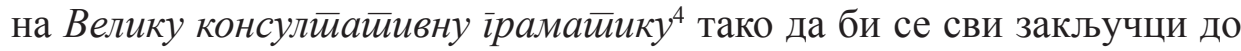
којих бисмо дошли при анализи овог дела заправо односили на други том Велике консулитайивне ірамайике из 1991. године.

Као што ће централни део рада и показати најзначајније карактеристике савременог проучавања зависних реченица јесуновине у погледу терминологије које се јављају услед све већег окретања ка генеративној и депенденцијалној граматици у чијим се основама

3 Друго издање ове граматике, рађено у коауторству са Кристијаном Де Сантис, штампано је 2011. године. Аутори у уводу истичу како друго издање теоријску, методолошку али и општу поставку дела преузима од првог издања граматике из 2006. Једина разлика јесте одсуство поглавља о стилским фигурама које није пронашло своје место у оквиру другог издања искључиво због обимности садржаја. Ми смо за потребе наше анализе користили издање из 2011.

4 Ово дело је чак сматрано врстом „еditio minor“ Велике консулйайивне ірамайике мада сами аутори у предговору другом издању наглашавају да њихово дело ипак не представља њено скраћено издање (2004: 12). 
налази подела на нуклеус реченице односно на елементе који су у реченици обавезни и маргинални део односно реченичне експанзије које не представљају неопходне делове реченица. С тим у вези, у савремену италијанску синтаксу зависносложене реченице, уведена је примарна подела на нуклеус који подразумева тематске то јест допунске реченице (о разлици између ова два термина више у централном делу рада) и на, како их Пранди (2006) назива, маргиналне реченице то јест оне које представљају експанзију нуклеуса и тичу се разних прилошких значења ${ }^{5}$. Данашње класификације се обавезно темеље на управо изложеној разлици. Прилично значајна класификациона новина јесте положај релативних реченица. До Велике консулитайивне ірамайике ове реченице су најчешће класификоване или као једна од три примарне групе зависних реченица (придевске, атрибутске) или, чешће, само као једна од бројних врста зависних реченица. Међутим, ова граматика уводи новину у том погледу што релативну реченицу не анализира у оквиру субординације већ у делу граматике посвећеном именичкој синтагми, што се објашњава тиме да релативна реченица заправо представља модификатор номиналног елемента (Самарџић 2009: 841). Ипак, савремене италијанске граматике, што ће и показати наша анализа, релативну реченицу задржавају у оквирима субординације тумачећи је међутим посебно и издвојено: најчешће је не уводе у примарну поделу будући да је она двочлана, а не трочлана као раније, већ ову врсту анализирају у засебном поглављу или у поглављу посвећеномтакозваним реченицама у оквиру синтагме (Ферари \& Цампезе (Ferrari \& Zampese 2016). Управо у случају реченица у оквиру синтагме, долазимо до још једне новине модерне италијанске граматикографије, а то су допунске реченице уведене именицом или придевом. Наиме, поједини савремени италијански граматичари (Ло Дука \& Соларино (Lo Duca \& Solarino 2004), Пранди 2006, Ферари $\&$ Цампезе 2016) у оквиру субординације класификују и допунске реченице које зависе од одређене групе именица или придева што мења основну поставку субординације по којој зависна реченица зависи ис-

5 Примарна подела зависних реченица у традиционалним италијанским граматикама, уколико је била уведена (чешће су граматике без икакве примарне поделе реченица), односила се на допунске, придевске (атрибутске) и прилошке реченице. 
кључиво од глагола управне реченице. Наравно, традиционалне италијанске граматике нису занемаривале рекцију одређених именица и придева према којој могу фигурирати као управни елемент зависне реченице, те тако Серијани (1988: 550) примећује да ова могућност одређених именица и придева открива недостатак тврдње по којој је објекатска реченица једнака објекту просте реченице будући да именица или придев не би никако могли имати допуну у виду објекта. Серијани се ту, уз констатацију да су овакви примери далеко ређи, зауставља не посвећујући више пажње реченицама чији је управни елемент номинална реч.

Веће разлике у односу на традицоналну граматику, али и у међусобном односу савремених граматика, показују се у класификацији и терминолошком одређивању примарних група зависних реченица, док су разлике у класификацијама и обради реченица које представљају подврсте допунских и прилошких далеко мање. Међу савременим граматикама те разлике су пре свега квантитативне природе док квалитативних разлика готово уопште да нема, док се у односу на традиционалне граматике разликују пре свега због изостављања одређених врста зависних реченица (месне реченице, изјавне реченице).

\section{2. Анализа поглавља о зависносложеној реченици}

Граматика аутора Трифонеа и Палерма као и дело Чечилије Андорно деле готово идентичну поставку анализе зависносложене реченице. Наиме, у оба деле полази се од претпоставке о супростављености тематских реченица које припадају нуклеусу и нетематских које су ван граница нуклеуса. У прву групу реченица, традиционално познатих под називом допунске реченице (proposizioni completive), Трифоне и Палермо убрајају објекатске, изјавне, субјекатске, зависно-упитне и индиректне тематске реченице (argomentali oblique), док Андорно своју класификацију ограничава на субјекатске, објекатске и такозване индиректне реченице $\left(\right.$ oblique $^{6}$. Термин „тематске рече-

6 Као што се и може уочити, класификацију коју уводи Андорно разликује од класификације коју предлажу Трифоне и Палермо изостављање изјавних и зависноупитних реченица. Наиме, питање изјавних реченица у италијанским граматикама је врло сложено будући да је њихово место у класификацијама зависних реченица нестално, док се њихово постојање тумачи на основу два критеријума: семантич- 
нице“ се у италијанским граматикама среће прилично ретко, а први

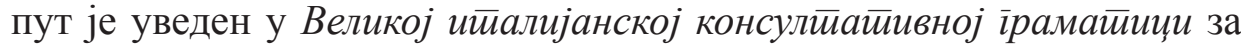
одређивање реченица које су део нуклеуса и стоје насупрот прилошким реченицама (proposizioni avverbiali). Међутим, у овој граматици није изједначен са термином „допунске реченице“, као што је то случај у Трифоне \& Палермо и Андорно, већ подразумева „надврсту“ која обухвата субјекатске и допунске реченице? . Такође, одређивање такозваних „индиректних“ објекатских односно допунских односно тематских реченица представља новију појаву у италијанској грама-

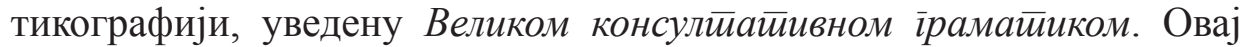
појам се односи на имплицитне објекатске реченице уведене предлозима $d i$ или $a$ које су италијански граматичари одувек анализирали али без неког посебног терминолошког одређивања.

Иако је у примарној подели начињена искључиво дистинкција између тематских и нетаматских реченица, аутори оба дела, засебно у оквиру поглавља о зависносложеној реченици, изван било које класификације, анализирају релативне реченице прецизирајући да се оне не односе на целу управну реченицу већ на само један њен елемент који се назива антецедентом.

ког и формалног. Будући да нам оквири овог рада не дозвољавају да се упустимо у детаљнију анализу изјавних реченица, нагласили бисмо да је врло важно истаћи да сеове реченице, што се тиче италијанске граматикографије, увек јављају код аутора који заступају традиционални граматички модел, те се стога може закључити да се у граматици Трифоне \& Палермо прилично видљиво преплићу традиционални

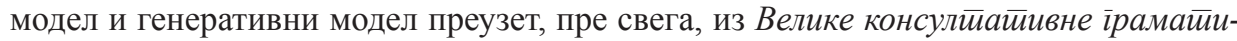
ке. Место зависно-упитних реченица није у овој мери комплексно с обзиром на то да се од најранијих до најсавременијих италијанских граматика ове реченице класификују како у истој равни са субјекатским и објекатским тако и као подврста објекатских реченица. Анализе показују да се одређени начин класификовања ових реченица не може довести у везу са одређеним теоријским моделом.

7 На класификационо раздвајање субејактских и објекатских реченица наишли

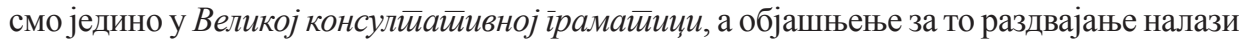
се у теорији генеративне граматике према чијим се критеријумима субјекат и објекат не налазе у истој равни односно немају исти стаутус у односу на глагол. Донати (Donati) $(2012: 79,80)$ истиче постојање хијерархије међу допунама глагола. Прецизира да је глагол тешње повезан са објекатом него са субјектом из разлога што објекат може да утиче на интерпретацију субјекта (може да утиче на промену тематске улоге субјекта), док субјекат никада не може утицати на промену интерпретације објекта . 
Што се тиче реченица изван нуклеуса, Трифоне \& Палермо их називају нетематским реченицама, док се Андорно одлучује за појам „subordinate non nucleari” односно зависне ненуклеарне реченице прецизирајући да оне изражавају како прилошка тако и циркумстанцијална значења. Класификација у Трифоне \& Палермо је незнатно разгранатија и подразумева узрочне, намерне, последичне, допусне, условне, временске, начинске, супротне, искључујуће, искључне и лимитативне, док су у Андорно врло сажето анализиране временске, узрочне, намерне, допусне, а нешто опширније су испитане условне, последичне и поредбене реченице.

У граматици Ло Дука \& Соларино осим стандардне поделе зависних реченица према логичко-семантичкој функцији, уведена је и подела на основу такозваних „punti d'attacco delle frasi subordinate”. Према овом критеријуму подела је извршена на реченице које се „каче“ на глагол, реченице које се „каче“ на именицу, реченице које се „каче“ на придев и реченице које се „каче“ на целу реченицу. Овакав формални критеријум за класификацију зависних реченица је прилично јединствен у италијанској граматикографији будући да су традиционални граматичари, уколико су уводили и формалну поделу реченица, заступали поделу на основу глаголског начина зависне реченице. Што се тиче логичко-семантичког критеријума, он је у потпуности у складу са традицијом и подразумева следеће врсте зависних реченица: субјекатске, објекатске, релативне, временске, намерне, узрочне, погодбене, последичне, допусне, начинске, поредбене, искључне, искључујуће, лимитативне, супротне и додатне. Као што се може приметити, у овој граматици не постоји примарна подела реченица у оквиру логичко-семантичког критеријума, што је изузетак у погледу савремених граматика, а такође није уочено позивање на дистинкцију нуклеус/експанзије иако је више пута наглашено да зависне реченице одговарају или обавезном или факултативном елементу.

Дело Микелеа Прандија је због своје теоријске поставке, засноване превасходно на постулатима такозване филозофске граматике, јединствено у италијанској граматикографији. Како се и може закључити из самог наслова дела, анализа и опис италијанског језика су извршени уз константно позивање на разлику између ірамайике иравила и ірамайике избора тачније на разлику између онога што у 
језику нема алтернативну могућност и онога што може бити изречено на више начина. Како је наведено у предговору (2011: XXI) на пољу фонологије и морфологије не постоје избори већ је у питању искључиво граматика правила, а тек се на нивоу реченице може говорити о дистинкцији између граматике избора и граматике правила. Разликовање граматике правила и граматике избора упућује заправо на две велике тенденције данашње лингвистике: формалну која у језику на првом месту уочава систем структура које функционишу према одређеним правилима и фукционалну која у језику види извор језичких и граматичких чинилаца које стоје на услузи говорницима (ibid: XX). Граница између области правила и области избора упућује на разлику у режиму кодификовања (ibid: XXV) и заправо друга два појма на којима Пранди заснива своју граматичку анализу јесу појмови кодификовања (codifica) и инференције (inferenza $)^{8}$. Кодификовање представља начин на који синтаксичке структуре доводе до изражавања појмовног садржаја (ibid) и може се говорити о три врсте кодификовања (ibid: XXVII): пуно кодификовање (codifica piena), хипокодификовање (ipocodifica) и хиперкодификовање (ipercodifica). Пример за први тип јесте везник „упркос“( (nonostante) који увек може имати једино допусно значење и у могућности је да кодификује на једнозначан начин дату појмовну релацију. Други тип кодификовања је објашњен помоћу предлога „са“ (con) који може означавати како инструмент тако и друштво, док се хиперкодификовање односи на то да се одређено значење не ограничава искључиво на један концептуални садржај.

Структура поглавља о сложеној реченици је нешто другачија него у осталим граматикама. Прво поглавље посвећено сложеној реченици јесте четврти део граматике насловљен Il periodo come frase complessa. Зависне реченице дели, пре свега, на допунске и маргиналне реченице и истиче да је за њихово проучавање најважније најпре направити јасну разлику међу њима, те сходно томе објашњава да допунске реченице улазе у структуру нуклеуса док маргиналне реченице проширују главни процес повезујући га са неким другим процесом. Наглашава, такође, да је код допунских реченица у питању граматика

8 Појам из филозофије који се односи на доношење закључака на основу уочених или претпостављених чињеница. 
правила (grammatica delle regole) будући да је процес јединствен и не постоји алтернатива којом би се тај процес исказао, док је код маргиналних реченица у питању граматика избора (grammatica delle scelte) стога што је реч о два независна процеса који се повезују, а за то њихово повезивање постоји још много алтернативних начина. Допунске реченице су истовремено и допуне (argomenti) неког глагола те је стога код њиховог проучавања важно издвојити групе глагола који их уводе. Маргиналне реченице, с друге стране, представљају повезивање различитих процеса те се њихово проучавање заправо своди на проучавање средстава која омогућују повезивање процеса. Пранди у допунске реченице убраја објекатске, зависно-упитне (наводи да су тип објекатских) и субјекатске реченице. Након ових реченица уведена је анализа реченица „које зависе од именица и придева“ односно релативних реченице и допунских реченица уведених именицом или придевом.

Наредно пето поглавље посвећено је кохеренцији и кохезији текста док је шесто поглавље, насловљено Sul confine tra frase e testo: l'espressione delle relazioni transfrastiche, посвећено ономе што би традицинална граматика назвала прилошким реченицама. Како се и види из наслова поглавља, а и из напомена аутора на почетку истог, релације које могу бити, на пример, узрочне, допусне, временске могу се изразити не само субординацијом већ и координацијом, јукстапозицијом али и трансреченично то јест на нивоу текста. Управо због тога, прецизира се у уводу (2011: XXXI), поглавље о кохеренцији и кохезији текста претходи поглављу о сложеној реченици тачније о повезивању различитих процеса путем такозваних йојмовних мостиова. Такође, врло значајно запажање на коме ће се и темељити проучавање сложених реченичних структура тиче се чињенице да се идентичном формом сложене реченице могу изразити различите релације док једна иста релација може бити изражена различитим формама сложене реченице. Тако, на пример, узрочна реченица може изразити како разлог тако и мотив људског деловања. С друге стране, намера може бити изражена како финалном тако и каузалном формом (стр. 293). Стога у овој граматици полазна тачка нису форме зависних реченица нити садржај везника већ појмовне везе путем којих се проучавају различите форме изражавања (субординација, координација, јукстапози- 
ција) (ibid). Приликом проучавања различитих начина изражавања исте трансреченичне релације кориштен је појам „лингвистичког кодификовања““. Степен кодификовања, о коме је малочас било речи, у случају реченичних релација помаже да се процени у којој су мери средства изражавања (везници и предлози, анафорички изрази, времена и начини) у могућности да обавежу неки одређени тип релације.

При обради маргиналних реченица, Пранди најпре усваја разлику између „формалних релација међу процесима“ и „појмовних релација међу процесима““. Формална релација се односи на истинитост односно неистинитост (verità efalsità) реченица које повезује. Два основна типа формалних релација јесу саставна веза кодификована обично напоредним везником $u$ и раставна веза кодификована обично напоредним везником или. ${ }^{9}$ Наводећи да су у питању виђења формалне логике, Пранди објашњава да саставна релација захтева да обе реченице буду истините док раставна релација захтева да барем једна (или обе) буду истините. С тим у вези, на крају закључује да супротна, временска, узрочна, допусна релација имплицирају процесе који се узимају као истинити, док условна релација остаје изван ових појмова због тога што се протазом искључује реалност.

Поглавље о појмовним релацијама се заправо бави значењем зависних маргиналних реченица у традиционалном смислу. Најпре су издвојене супротна и временска релација. Након њих следи поглавље о „мотивима деловања“ у оквиру кога су представљене узрочне реченице које не изражавају само узрок већ и мотив радње. У оквиру истог поглавља представљена је намерна релација коју Пранди не посматра као засебну појмовну релацију већ као специфичну узрочну форму која изражава једну врсту мотива. Даље су уведене и описане последичне, допусне и условне релације, а на самом крају инструменталне, искључујуће, лимитативне, искључне и поредбене конструкције.

На самом крају своје граматике Ђузепе Патота, у некој врсти поговора (стр. 462, 463), истиче да је првобитни циљ ове граматике свеобухватан и строго научан опис структура италијанског језика који ће истовремено бити и јасан и доступан свима. И стога, да би у томе успео, аутор је одустао од употребе граматичког, било тради-

9 Пранди за ове две формалне релације користи термине cooccorrenzaи alternativa. 
ционалног било савременог, метајезика као и од навођења теоријских напомене које не би имале непосредну практичну примену. Такође, граматичка анализа у овој граматици не поседује никакав специфичан редослед што је уобичајено у осталим италијанским граматикама $^{10}$ већ је аутор одабрао да примени циркуларни ток обрађујући притом заједно морфолошке и синтаксичке теме. Стога, у складу са оваквом поставком граматике, читалац неће наићи на посебно поглавља о зависносложеној реченици већ ће о субординацији спорадично бити речи у оквиру других поглавља. Релативну реченицу заједно са релативном заменицом проучава у оквиру поглавља Forme e frasi (Облици и реченице). Прилошке реченице у трећем поглављу насловљеном Rapporti (Односи) у ком су издвојени неки од главних односа и све могућности њиховог изражавања у језику. Први део је, на пример, назван Collegare, aggiungere, escludere (Повезивање, додавање, искључивање) у оквиру кога су на одговарајућим местима издвојене додатна реченица, искључна, искључујућа и лимитативна реченица. Следеће поглавље говори о изражавању контраста у језику те се стога ту говори о допусној реченици. Зависна супротна реченица је издвојена у оквиру поглавља Diversità (Различитост). У одговарајућим поглављима обрађене су временска, начинска, намерна, узрочна, последична и погодбена реченица. Ипак, на самом крају граматике Патота додаје неку врсту апендикса у оквиру ког обрађује осамдесет основних појмова из синтаксичке анализе просте и сложене реченице међу којима издваја и обрађује и мање-више све традиционалне врсте зависних реченица: објекатске, субјекатске, изјавне, зависно-упитне, узрочне, намерне, последичне, условне, допусне, временске, супротне, поредбене, поредбено-условне, начинске, додатне, искључујуће, искључне, лимитативне, релативне.

Граматика аутора Франческа Сабатинија, Кармеле Камодека и Кристијане Де Сантис представља средњошколску граматику засновану на теорији валентности. Распоред проучавања зависних реченица

10 Патота истиче (стр. 462) да се италијанске граматике, према редоследу граматичке анализе, деле у две категорије: граматике које поседују „опадајући“ редослед (од општег ка посебном, од реченице ка реченичним елементима) и граматике које поседују „растући“ редослед (од посебног ка општем, од конститутивних елемената ка реченици). 
је прилично другачији него у осталим граматикама било да припадају традиционалном било генеративном моделу. Наиме, у овој граматици анализа допунских и релативних реченица дата је у оквиру поглавља о простој то јест у оквиру „трансформација нуклеуса“, а релативне у оквиру прилошких одредби (circostanti). Прецизирано је да допунске реченице зависе директно од глагола и стога их треба разликовати од зависних реченица које се налазе ван нуклеуса, зависе од целе главне реченице и трансформишу просту реченицу у сложену. Сабатини и др. у допунске реченице убрајају субјекатске, директне објекатске (у које спадају и зависно-упитне) и индиректне објекатске. На крају поглавља о простој реченици уводи се појам експанзија на који се надовезује проучавање сложене реченице коју ови аутори називају frase multipla ${ }^{11}$. Издвајају следеће врсте реченица: узрочне, допусне, намерне, временске, погодбене, начинске, супротне, искључне, искључујуће, лимитативне. Посебно издвајају и анализирају последичне и поредбене реченице називајући их једним именом међузависне реченице (frasi interdipendenti) ${ }^{12}$. Издвајање такозваних међузависних реченица је одлика коју смо запазили искључиво у овом делу међутим, с обзиром на то да аутори под тим реченицама сматрају поредбене и последичне, изнећемо једно краће запажање. Наиме, у историји италијанске граматикографије су се у неколико наврата могли уочити термини periodo comparativo (Парато (Parato) 1923, Карамело \& Capaco (Caramello\&Sarasso) 1959) као и periodo consecutivo (Батаља \& Перниконе (Bataglia\&Pernicone) 1951) иако је овакво одређивање зависно сложене реченице (инсистирање на њеној целини) општеприхваћено само за хипотетичку сложену реченицу (periodo ipotetico) због изузетно јаке везе зависне и главне реченице. Стога се на основу тер-

11 Овај термин уводи и употребљава једино Сабатини у италијанској граматикографији. Сложена реченица се, углавном, означава терминима periodo, frase composta или frase complessa чијем се изједначавању данас тежи док су у прошлости граматичири ове термине употребљавали како би означили различите појмове. Више о развоју ових термина у Графи (Graffi) 2009.

12 Прецизирано је да се у случају ових реченица не може говорити о једној управној и једној зависној реченици већ више о две међузависне реченице будући да управна реченица није сасвим самостална због тога што садржи елемент чије постојње се обравдава једино у односу за зависном реченицом (стр. 398). 
мина који су користили поменути старији граматичари, али и експлицитног објашњења у Сабатини и др. закључује да су јака повезаност, целина и међузависност бивале препознате од стране италијанских граматичара и у случају зависносложених реченица које изражавају поређење односно последицу.

Последња објављена релевантна граматика италијанског језика јесте дело двоје уважених швајцарских италијаниста Анђеле Ферари и Лучана Цампезеа. Примарна подела зависних реченица је формална и тиче се реченица које зависе од глагола и реченица у оквиру синтагме (зависе од номиналног елемента). Реченице уведене глаголом деле се даље узимајући у обзир дистинкцију између нуклеуса и експанзија на тзв. нуклеарне реченице (proposizioni nucleari) и циркумстанцијалне реченице (proposizioni circostanziali). Нуклеарне реченице су даље подељене на субјекатске, објекатске и зависно-упитне. Што се тиче циркумстанцијалних дате су две поделе ${ }^{13}$ : прва на основу основу форме, а друга на основу значења. У оквиру прве поделе засноване на форми, издвојене су реченице са темпорализованим предикатом, реченице са инфинитивом, са герундијумом и реченице са партиципом. У оквиру друге поделе засноване на значењу, аутори у засебним поглављима описују узрочне, намерне, последичне, условне, допусне, временске, поредбене, лимитативне, супротне, начинске, искључне и додатне реченице.

\section{3. Закључак}

Као што смо и нагласили у уводу и имали могућности да покажемо у централној анализи, данашњу италијанску граматикографију не одликује јединствени и хомогени теоријски модел већ комбинација генеративног, депенденцијалног и традиционалног модела. У прилог тој тези говори и чињеница да савремена италијанска граматикографија не поседује граматику урађену у потпуности према постулатима генеративне граматике, а што се, пре свега, огледа у неприказивању структуре реченица синтаксичким стаблима, што је једна од основних

13 Двојака подела реченица, према формалном и према логичко-семантичком критеријуму, није ретка појава у италијанској граматикографији, а такву поделу

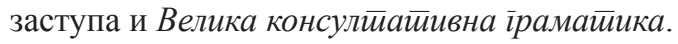


карактеристика генеративне граматике ${ }^{14}$. Референтна граматика јесте

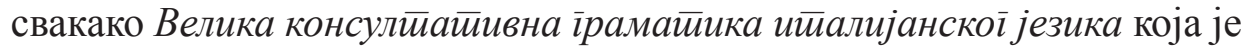
и створена са циљем да служи као модел при стварању мањих, практичних граматика. Међутим, уочили смо нека незнатна удаљавања нових граматика када је у питању проучавање зависносложене реченице: пре свега место релативних реченица је и даље у оквиру субординације (у овом погледу се издваја једино граматика Сабатини и др. у којој се анализи релативних реченица, али и допунских, приступа у оквиру поглавља о простој реченици), док се појам тематских реченица употребљава нешто другачије. Што се тиче релативних реченица, уочено је да њихово место при класификацијама зависних реченица данас представља проблем, будући да их, свакако с правом, аутори посматрају као реченице које зависе од номиналног елемента и припадају синтагми, али их, због свођења поделе реченица на оне које припадају нуклеусу и оне које не припадају нуклеусу, више не могу класификовати као једну од три примарне групе зависних реченица што је био случај у традиционалним граматикама. Стога, из управо изнетих разлога, релативне реченице бивају искључене из примарних класификација зависних реченица и њиховој анализи се приступа у засебним поглављима у оквиру субординације. Ипак, можда и највећа новина савремених анализа зависносложене реченице јесу допунске реченице уведене номиналним елементом које бивају класификоване заједно са релативним реченицама.

Анализираним граматикама заједнички је основни приступ у анализи зависноложене реченице према коме се зависне реченице деле у две категорије: обавезне и необавезне. С друге стране, уочљиве су благе разлике по питању терминологије и класификација. Што се терминолошких разлика тиче, најизраженије су оне које се односе на именовање реченица које припадају нуклеусу будући да термини варирају између „тематске“, ,„опунске“ и „нуклеарне“, а слично је и са терминолошким одређивањем реченица које не припадају нуклеусу будући да су у употреби термини „нетематске, „маргиналне“, „цир-

14 Иако не постоје граматике које преузимају овакав начин приказивања структуре реченица, бројни су приручници из синтаксе који користе синтаксичка стабла (нпр, Донати 2008, Фраскарели, Рамаља\& Корпина (Frascarelli, Ramaglia\&Corpina 2012)). 
кумстанцијалне“. По питању класификације можемо рећи да постоје два типа граматика: оне које заступају двочлану примарну поделу према логичко-семантичком критеријуму и оне које заступају двојаку класификацију (формалну и логичко-семантичку). И најзад, дело Ђузепеа Патоте излази из свих до сада постављених оквира, будући да овај аутор примењује, већ поменути, циркуларни редослед због чега се и не може говорити о постојању неке одређене класификације или примарне поделе реченица што само потврђује чињеницу о разноврсности савремене италијанске граматикографије.

\section{ЛИТЕРАТУРА:}

Andorno, C. (2003). La grammatica italiana. Milano:Mondadori.

Andreose, A. (2017). Nuove grammatiche dell'italiano. Roma: Carocci.

Battaglia, S., Pernicone, V. (1951). La Grammatica Italiana. Torino: Loescher.

Blasco Ferrer, E. (1990). Recensione a GGIC I, Serianni (1988), Schwarze (1988). Romanistisches Jahrbuch 41, 185-93.

Caramello, C., Sarasso, T. (1959). Come si dice... Come si scrive... Grammatica italiana per la scuola media. Torino: Paravia.

Castelaro, R. (2005). Italiano insieme. Torino: Il Capitello.

Costabile, N. (1967). Le strutture della lingua. Bologna: Patron.

Donati, C. (2008). La sintassi. Regole e strutture. Bologna: Il Mulino.

Donati, C. (2012). Sintassi elementare. Roma: Carocci.

Ferrari, A., Zampese, L. (2016). Grammatica: parole, frasi, testi dell'italiano. Roma: Carocci.

Frascarelli, M., Ramaglia, F., Corbina. B. (2012). Elementi di sintassi. Cesena: Caissa Italia.

Gamberini, S. (1971). Il ragazzo guarda il mondo: grammatica trasformazionale della lingua italiana : per la scuola media. Messina-Firenze: Casa editrice G.D’Anna.

Graffi, G. (2009). Origini e sviluppo della nozione di subordinazione frasale nella grammatica italiana. In: A. Ferrari (a cura di), Atti del X Congresso della SILFI (Basilea, 30 giugno - 3 luglio 2008). Sintassi storica e sincronica dell'italiano.Vol. I. (pp. 59-100). Firenze: Franco Cesati.

Lepschy, G. (1972). La grammatica italiana: problemi e proposte. In: Scritti e ricerche di grammatica italiana.(pp. 3-13). Trieste: Edizioni Lint. 
Lo Duca, M. G., Solarino, R. (2004). La lingua italiana. Una grammatica ragionevole. Padova: Unipress.

Panebianco, B., Pisoni, C., Reggiani, L. (2012). Grammatica italiana. Bologna: Zanichelli.

Parato, G. (1923). Nuova grammatica della lingua italiana. Torino: Paravia.

Parisi, D., Antinucci, F. (1973). Elementi di grammatica. Torino: Boringhieri.

Patota, G. (2006). Grammatica di riferimento dell'italiano contemporaneo. Novara: De Agostini.

Prandi, M., De Santis, C. (2011). Le regole e le scelte. Manuale di linguistica e di grammatica italiana. Novara: De Agostini.

Renzi, L. (a cura di). (1988). Grande grammatica italiana di consultazione, I. Bologna: Il Mulino.

Renzi, L. e Salvi, G. (a cura di). (1991). Grande grammatica italiana di consultazione, II. Bologna: Il Mulino.

Roncoroni, F. (2006). Grammatica essenziale della lingua italiana. Milano: Mondadori.

Sabatini, F., Camodeca, C., De Santis, C. (2011). Sistema e testo: dalla grammatica valenziale all'esperienza dei testi. Torino: Loescher.

Saltarelli, M. (1970). La grammatica generativa trasformazionale : con introduzione alla fonologia, sintassi e dialettologia italiana. Firenze: Sansoni.

Salvi, G., Vanelli, L. (2004). Nuova grammatica italiana. Bologna: Il Mulino.

Samardžić, M. (2009). La grammaticografia italiana all'inizio del Duemila: nuovi approcci alla sintassi del periodo. In: A. Ferrari (a cura di), Atti del $X$ Congresso della SILFI (Basilea, 30 giugno - 3 luglio 2008). Sintassi storica e sincronica dell'italiano. Vol. II. (pp. 837-855). Firenze: Franco Cesati.

Schwarze, C. (1988). Grammatik del italianischen Sprache. Tubingen: Max Niemeyer Verlag.

Serianni, L. (con la collaborazione di A. Castelvecchi). (1988). Grammatica italiana. Italiano comune e la lingua letteraria. Torino: Utet.

Trifone, P., Palermo, M. (2000). Grammatica Italiana di Base. Bologna: Zanichelli.

Vanelli, L. (2012). Grammatiche dell'italiano e linguistica moderna. Padova: Unipress. 
Марија Митровић

\title{
Marija Mitrović
}

\section{LA SINTASSI DELLE FRASI SUBORDINATE NELLE GRAMMATICHE CONTEMPORANEE DELLA LINGUA ITALIANA}

\begin{abstract}
Riassunto
L'obiettivo del presente contributo è di presentare i nuovi approcci all'analisi (terminologia, classificazioni, modelli teorici) delle frasi subordinate nelle grammatiche contemporanee della lingua italiana prendendo in considerazione le opere più rilevanti pubblicate nei primi decenni del XXI secolo. Le analisi mostrano che la grammaticografia italiana contemporanea non propone un modello omogeneo bensì una specie di combinazione tra il modello tradizionale, il modello generativo e quello valenziale. Lo studio delle frasi subordinate è basato sulla distinzione tra le proposizioni necessarie che fanno parte del nucleo (completive / argomentali / nucleari) e le proposizioni non necessarie che non fanno parte del nucleo (marginali / non argomenatli / non nucleari). In quanto gli autori propongono una classificazione del genere, le proposizioni relative ne restano fuori cosicché il loro posto è alquanto indefinito. La più grande innovazione sono le cosiddette "proposizioni incluse in un sintagma della reggente", le quali si riferiscono alle proposizioni relative nonché alle completive introdotte da un elemento nominale. Le differenze più notevoli nell'ambito delle grammatiche contemporanee riguardano l'uso della terminologia e il criterio su cui viene basata la classificazione mentre le differenze riguardo alla tradizione si rilevano nella suddivisione primaria delle frasi subordinate nonché nella semplificazione delle classificazioni e nell'omissione di alcune proposizioni subordinate presenti nelle grammatiche tradizionali (dichiarative, locative).
\end{abstract}

Parole chiave: frasi subordinate, nucleo, espansioni, proposizioni completive, proposizioni avverbiali 